\title{
Stability of Hydrocortisone, Nifedipine, and Nitroglycerine Compounded Preparations for the Treatment of Anorectal Conditions
}

\section{INTRODUCTION}

Anal fissure is a painful condition associated with hypertonia of the internal anal sphincter. ${ }^{1-4}$ Treatments are aimed at relaxing the internal sphincter, reducing pain, and increasing local blood flow, which stimulates fissure healing. Treatments include hydrocortisone, nitroglycerine, and calcium-channel blockers, such as nifedipine and diltiazem. ${ }^{5-11}$

The choice of base is an important consideration when compounding preparations. Nonaqueous bases such as petrolatum offer better adherence and longer residence time than creams. Furthermore, preparations are typically more stable in nonaqueous bases, because hydrolysis is less likely in the absence of water. ${ }^{12}$ For instance, the US Pharmacopeia recommends maximum beyonduse dates (BUDs) in the absence of stability information of not more than 6 months for nonaqueous formulations and not more than 30 days for water-containing topical formulations. ${ }^{13}$

Hydrocortisone $2.5 \%$ in petrolatum, nifedipine $0.5 \%$ in petrolatum, and nitroglycerine $0.2 \%$ in petrolatum are not available as commercial formulations, and stability studies for these preparations have not been reported. Currently, pharmacists prepare the formulations and assign a default BUD based on recommendations in General Chapter <795> of the US Pharmacopeia. ${ }^{13}$ Formal stability testing is required to determine a BUD based on scientific data.

For the current study, the stability of these 3 preparations, as well as hydrocortisone $2.5 \%$ in a cream base, was evaluated over a 12 -month period. Hydrocortisone $2.5 \%$ in a cream base was chosen for comparison because it is in common use. The nitroglycerine preparation was stored in both polypropylene and glass containers, to allow evaluation of possible sorption on the inside of plastic containers.

\section{METHODS}

\section{Sample Preparation}

Nifedipine $0.5 \%$ in petrolatum: Nifedipine USP was accurately weighed and transferred to a glass plate $(750 \mathrm{mg}$; Galenova, Saint-Hyacinthe, Quebec; lot 12345-3344, expiry August 2015). The powder was mixed, using a spatula, with white petrolatum USP to form a uniform smooth paste $(3 \mathrm{~g}$; Medisca Pharmaceutique Inc, Montréal, Quebec; lot 51490/B, expiry May 2016). Additional petrolatum was incorporated, in increments, to attain the required final total weight (150 g). The homogeneous, semisolid preparation was packaged in 3 white opaque $50-\mathrm{mL}$ polypropylene containers (30 g per container; Jones Packaging, Brampton, Ontario; lot 16J0505). The 3 containers were stored at $25^{\circ} \mathrm{C} \pm 2^{\circ} \mathrm{C}$ and $60 \% \pm 5 \%$ relative humidity in a Forma environ- 
mental chamber (Thermo Scientific, Rochester, New York). The remaining preparation was used for time zero analysis and then discarded. Nifedipine is known to be photosensitive. ${ }^{14}$ Exposure to direct light was avoided by performing manipulations under indirect fluorescent lighting. For manipulations that could not be done in opaque containers, aluminum foil was used to protect the samples from light.

Hydrocortisone $2.5 \%$ in petrolatum: This formulation was prepared and packaged as described above, with replacement of nifedipine USP by hydrocortisone USP (3.75 g; Medisca Pharmaceutique Inc; lot 53383/E, expiry October 2015).

Hydrocortisone $2.5 \%$ in cream base: This formulation was also prepared as described above, with replacement of white petrolatum USP by the same amount of a cream base (Mediderm, Medisca Pharmaceutique Inc; lot 1125/A, expiry February 2018).

Nitroglycerine $0.2 \%$ in petrolatum: Nitroglycerine ointment $2 \%$ USP was accurately weighed and then transferred to a glass plate (18 g of Nitrol 2\%; Paladin Labs, Montréal, Quebec; lot 472131, expiry July 2016). The ointment was mixed, using a spatula, with white petrolatum USP to form a uniform smooth paste ( $5 \mathrm{~g}$ petrolatum). Additional petrolatum was incorporated, in increments, to attain the required final total weight $(180 \mathrm{~g})$. The preparation was packaged in white opaque $50-\mathrm{mL}$ polypropylene containers and in $50-\mathrm{mL}$ amber glass containers (Galenova; product code 2220-1006-0012) and stored as described above for nifedipine.

\section{Organoleptic Evaluation}

At time zero and after 1, 2, 3, 6, 9, and 12 months, the content of each container was mixed with a spatula, and the preparations were inspected visually for consistency, colour, and odour changes.

\section{Sample Preparation for High-Performance Liquid Chromatography Analyses}

Samples were quantitatively transferred into $1.5-\mathrm{mL}$ centrifuge tubes, and dichloromethane was added $(85 \mathrm{mg}$ of test preparation in $900 \mu \mathrm{L}$ dichloromethane for nifedipine and hydrocortisone samples and in $400 \mu \mathrm{L}$ dichloromethane for nitroglycerine samples). The tubes were vigorously stirred using a vortex shaker until the ointment was completely solubilized. An aliquot of each solution was then diluted with methanol $(100 \mu \mathrm{L}$ of nifedipine solution with $750 \mu \mathrm{L}$ of methanol; $100 \mu \mathrm{L}$ of nitroglycerine solution with $580 \mu \mathrm{L}$ of methanol; and $20 \mu \mathrm{L}$ of hydrocortisone solution with $830 \mu \mathrm{L}$ of methanol) and refrigerated at $5^{\circ} \mathrm{C}$ for $15 \mathrm{~min}$ to precipitate the petrolatum. The supernatant was filtered through a syringe filter $(0.45 \mu \mathrm{m}$, nylon) and then analyzed by high-performance liquid chromatography (HPLC). Assuming a potency of $100 \%$ and a preparation density of $0.9 \mathrm{~g} / \mathrm{mL}$, the final concentration of nifedipine, hydrocortisone, or nitroglycerine in the injection samples was $50 \mu \mathrm{g} / \mathrm{mL}$ (calculation example for nifedipine: $0.5 \% \times 85 \mathrm{mg} /$ $(85 \mathrm{mg} / 900 \mathrm{mg} / \mathrm{mL}+0.9 \mathrm{~mL}) \times 0.1 \mathrm{~mL} /(0.1 \mathrm{~mL}+0.75 \mathrm{~mL})$ $=0.050 \mathrm{mg} / \mathrm{mL}=50 \mu \mathrm{g} / \mathrm{mL}$ ). Each injection was performed in duplicate. Each preparation was independently stored in 3 separate containers, and all containers were tested at all time points. Amber HPLC vials were used for the nifedipine-containing samples.

\section{Calibration Samples}

Calibration samples were similarly extracted from fresh mixtures of drug and vehicle to achieve target concentrations of $25,50,75$, and $100 \mu \mathrm{g} / \mathrm{mL}$.

\section{Stress Degradation Study}

A 5-g sample of each preparation was stored for 3 days at $80^{\circ} \mathrm{C}$ in a $20-\mathrm{mL}$ scintillation vial. The degraded preparations were sampled as described above and analyzed by HPLC.

\section{HPLC Assay}

The HPLC system (Prominence UFLC system, Shimadzu Scientific Instruments, Laval, Quebec) consisted of a vacuum degasser (DGU-20A5), an autosampler (SIL-20AC), a quaternaryflow solvent-delivery system (LC-20AD), a column oven (CTO-20AC), and a diode array detector (SPD-M20A). The exact conditions were optimized for each preparation, as described in Table 1.

\section{Data Analysis}

The chemical stability of each preparation was determined by evaluating the percentage of the initial concentration remaining at each time point. Chemical stability was defined as recovery of not less than $90 \%$ of the initial concentration of drug.

\section{Table 1. Chromatographic Conditions}

\begin{tabular}{lccc} 
Variable & Nifedipine & Hydrocortisone & Nitroglycerine \\
\hline PDA wavelength $(\mathrm{nm})$ & 235 & 245 & 210 \\
Mobile phase* & $\mathrm{A}: \mathrm{B} 45: 55$ & $\mathrm{~A}: \mathrm{C} 50: 50$ & $\mathrm{C}: \mathrm{D} 50: 50$ \\
Analysis time $(\mathrm{min})$ & 6 & 6 & 8.5 \\
Flow rate $(\mathrm{mL} / \mathrm{min})$ & 0.9 & 0.9 & 0.9 \\
Column temperature $\left({ }^{\circ} \mathrm{C}\right)$ & 40 & 40 & 40 \\
Sample temperature $\left({ }^{\circ} \mathrm{C}\right)$ & 20 & 20 & 20 \\
Injection volume $(\mu \mathrm{L})$ & 10 & 10 & 10 \\
Retention time $($ min) & 4.1 & 4.6 & 5.5 \\
PDA $=$ photodiode array. & \multicolumn{4}{l}{} \\
${ }^{*} \mathrm{~A}=\mathrm{KH}_{2} \mathrm{PO}_{4}$ in water $(20 \mathrm{mmol} / \mathrm{L}, \mathrm{pH} 3.0), \mathrm{B}=$ acetonitrile, $\mathrm{C}=$ methanol, $\mathrm{D}=$ water.
\end{tabular}




\section{RESULTS}

The linearity of the HPLC methods was evaluated between 0 and $100 \mu \mathrm{g} / \mathrm{mL}$. Triplicate injection of the standard solutions resulted in $r^{2}$ of 0.9999 , 0.9999, and 0.9999 for nifedipine, nitroglycerine, and hydrocortisone in petrolatum, respectively, and $r^{2}$ of 0.9998 for hydrocortisone in cream base. The accuracy of each calibration point relative to the regressed curve was between $98.3 \%$ and $100.6 \%$ for all HPLC analyses.

To evaluate recovery of the sample preparation, extracted samples of nifedipine, nitroglycerine, and hydrocortisone in petrolatum, as well as hydrocortisone in cream base, were compared with solutions of these active ingredients in a 1:1 mixture of methanol and water at a concentration of $50 \mu \mathrm{g} / \mathrm{mL}$. Extraction recovery was calculated as $107.3 \% \pm 0.5 \%, 105.9 \% \pm 1.0 \%$, and $107.2 \% \pm 0.1 \%$ for samples of nifedipine, nitroglycerine, and hydrocortisone in petrolatum, respectively, and as $96.2 \% \pm 0.1 \%$ for hydrocortisone in cream base.

Intraday and interday coefficients of variation were calculated from samples extracted in triplicate from preparations at concentrations equivalent to $50 \mu \mathrm{g} / \mathrm{mL}$ of active ingredient. These samples were evaluated in duplicate on 3 consecutive days. Intraday coefficients of variation calculated from 6 injections on the first day were $1.75 \%$, $0.23 \%$, and $0.86 \%$ for nifedipine, nitroglycerine, and hydrocortisone in petrolatum, respectively, and $0.56 \%$ for hydrocortisone in cream base. Interday coefficients of variation calculated from the first injection on 3 consecutive days were $0.62 \%, 0.84 \%$, and $0.15 \%$ for nifedipine, nitroglycerine, and hydrocortisone in petrolatum, respectively, and $0.19 \%$ for hydrocortisone in cream base.

Degradation samples obtained by heating for 3 days at $80^{\circ} \mathrm{C}$ (as described above) were analyzed by HPLC. No overlap was observed between the peak for the drug of interest and the degradation peaks for nifedipine (Figure $1 \mathrm{C}$; recovery $63.7 \%$ ) and nitroglycerine (Figure 1D; recovery 80.2\%), and no degradation products were obtained for hydrocortisone (Figure 1A). Because no degradation products were obtained with hydrocortisone under these conditions, the degradation study was repeated using a solution of hydrocortisone prepared at $1 \mathrm{mg} / \mathrm{mL}$ in a $1: 1$ mixture of methanol and water. This solution was submitted to acidic and oxidative conditions for $16 \mathrm{~h}$ at $60^{\circ} \mathrm{C}(1 \mathrm{~mL}$ of hydrocortisone $1 \mathrm{mg} / \mathrm{mL}$ with $1 \mathrm{~mL}$ of aqueous hydrochloric acid $1 \mathrm{~mol} / \mathrm{L}$ or $1 \mathrm{~mL}$ of aqueous hydrogen peroxide 3\%). After forced degradation under these conditions, the samples were diluted 10-fold using a 1:1 mixture of methanol and water and were analyzed by HPLC. This post hoc experiment allowed the formation of degradation products, which were clearly separated from the main peak; recovery of hydrocortisone was $68.2 \%$ and $55.2 \%$ under acidic and oxidative conditions, respectively (Figure 1B).

The stability results for each preparation are reported in Table 2. The percentage of drug remaining was calculated relative to the concentration at time zero. All preparations had an initial concentration between $90 \%$ and $110 \%$ of the target concentration. Furthermore, all preparations in petrolatum remained stable for the entire study period, as indicated by assay values of not less than $90 \%$ of the initial concentration. However, the hydrocortisone in cream base preparation was not stable after 3 months $(88.7 \%$ of initial concentration) and 6 months (81.8\%).

\section{DISCUSSION}

Hydrocortisone $2.5 \%$ in petrolatum, nifedipine $0.5 \%$ in petrolatum, and nitroglycerine $0.2 \%$ in petrolatum are nonaqueous preparations. They remained stable for at least 1 year when stored at $25^{\circ} \mathrm{C}$. Previous reports have highlighted the risk of sorption for

Table 2. Chemical Stability of Compounded Preparations for the Treatment of Anal Fissures

\begin{tabular}{|c|c|c|c|c|c|c|c|}
\hline \multirow{2}{*}{$\begin{array}{l}\text { Compound and } \\
\text { Container }\end{array}$} & \multirow{2}{*}{$\begin{array}{c}\text { Initial } \\
\text { Concentration } \\
(\% \text { w/w } \pm \text { SD) }\end{array}$} & \multicolumn{6}{|c|}{ Storage Time; Mean Concentration \pm SD $(\%, w / w)$ and Mean \% Remaining* } \\
\hline & & 1 month & 2 months & 3 months & 6 months & 9 months & 12 months \\
\hline Nifedipine & & & & & & & \\
\hline $\begin{array}{l}0.5 \% \text { in petrolatum, } \\
\text { polypropylene } \\
\text { container }\end{array}$ & $0.487 \pm 0.006$ & $\begin{array}{l}0.494 \pm 0.008 \\
(101.5)\end{array}$ & $\begin{array}{l}0.488 \pm 0.008 \\
(100.1)\end{array}$ & $\begin{array}{c}0.454 \pm 0.006 \\
(93.2)\end{array}$ & $\begin{array}{c}0.475 \pm 0.009 \\
(97.5)\end{array}$ & $\begin{array}{c}0.445 \pm 0.018 \\
(91.4)\end{array}$ & $\begin{array}{c}0.489 \pm 0.035 \\
(100.4)\end{array}$ \\
\hline \multicolumn{8}{|l|}{ Nitroglycerine } \\
\hline $\begin{array}{l}0.2 \% \text { in petrolatum, } \\
\text { polypropylene } \\
\text { container }\end{array}$ & $0.191 \pm 0.001$ & $\begin{array}{c}0.193 \pm 0.002 \\
(100.9)\end{array}$ & $\begin{array}{l}0.192 \pm 0.002 \\
(100.4)\end{array}$ & $\begin{array}{c}0.185 \pm 0.001 \\
(97.0)\end{array}$ & $\begin{array}{c}0.188 \pm 0.001 \\
(98.4)\end{array}$ & $\begin{array}{c}0.189 \pm 0.002 \\
(98.9)\end{array}$ & $\begin{array}{c}0.184 \pm 0.001 \\
(96.4)\end{array}$ \\
\hline $\begin{array}{l}0.2 \% \text { in petrolatum, } \\
\text { glass container }\end{array}$ & $0.194 \pm 0.001$ & $\begin{array}{c}0.196 \pm 0.004 \\
(101.1)\end{array}$ & $\begin{array}{l}0.196 \pm 0.001 \\
(101.0)\end{array}$ & $\begin{array}{c}0.191 \pm 0.002 \\
(98.5)\end{array}$ & $\begin{array}{c}0.193 \pm 0.001 \\
(99.7)\end{array}$ & $\begin{array}{c}0.194 \pm 0.003 \\
(100.4)\end{array}$ & $\begin{array}{c}0.194 \pm 0.001 \\
(100.0)\end{array}$ \\
\hline \multicolumn{8}{|l|}{ Hydrocortisone } \\
\hline $\begin{array}{l}2.5 \% \text { in petrolatum, } \\
\text { polypropylene } \\
\text { container }\end{array}$ & $2.64 \pm 0.02$ & $\begin{array}{l}2.65 \pm 0.00 \\
\quad(100.4)\end{array}$ & $\begin{array}{l}2.59 \pm 0.01 \\
(98.1)\end{array}$ & $\begin{array}{l}2.49 \pm 0.01 \\
\quad(94.2)\end{array}$ & $\begin{array}{l}2.53 \pm 0.01 \\
\quad(95.7)\end{array}$ & $\begin{array}{l}2.52 \pm 0.02 \\
\quad(95.3)\end{array}$ & $\begin{array}{l}2.54 \pm 0.02 \\
\quad(96.1)\end{array}$ \\
\hline $\begin{array}{l}02.5 \% \text { in cream base, } \\
\text { polypropylene } \\
\text { container }\end{array}$ & $2.50 \pm 0.01$ & $\begin{array}{c}2.30 \pm 0.02 \\
(92.2)\end{array}$ & $\begin{array}{l}2.50 \pm 0.04 \\
\quad(100.1)\end{array}$ & $\begin{array}{c}2.21 \pm 0.03 \\
(88.7)\end{array}$ & $\begin{array}{l}2.04 \pm 0.01 \\
\quad(81.8)\end{array}$ & NA & NA \\
\hline
\end{tabular}

$\mathrm{NA}=$ not applicable, $\mathrm{SD}=$ standard deviation.

* Mean values are based on 3 samples analyzed in duplicate. The percentage remaining is relative to the measured concentration at time zero. 

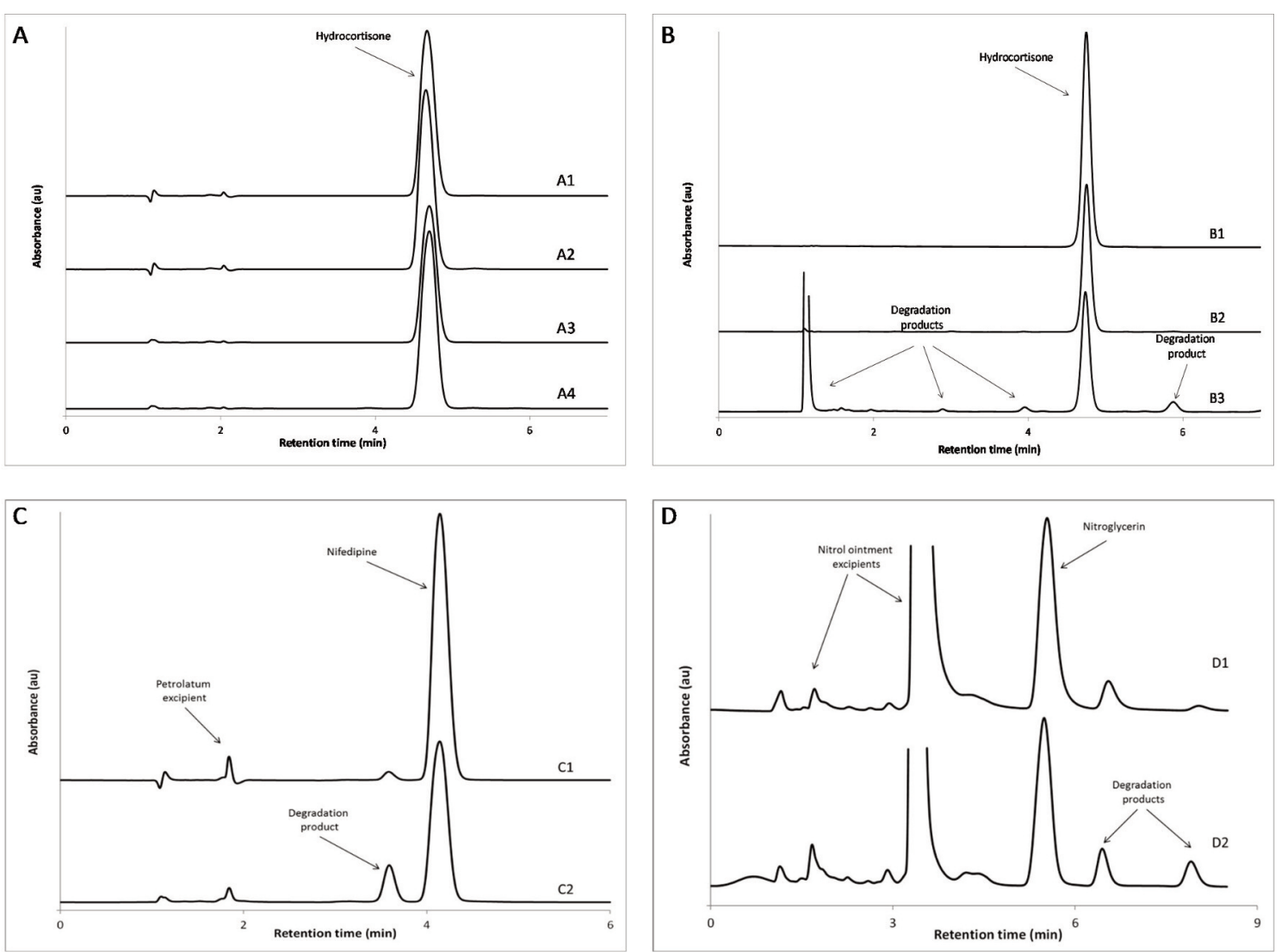

Figure 1. Representative chromatograms from stability studies of preparations used to treat anal fissures. A: Hydrocortisone preparations in petrolatum and cream base initially (A1 and A2, respectively) and after heating at $80^{\circ} \mathrm{C}$ for 3 days (A3 and $\mathrm{A} 4$, respectively). B: Hydrocortisone standard solution prepared in mobile phase at $50 \mu \mathrm{g} / \mathrm{mL}$ (B1); hydrocortisone sample degraded with hydrochloric acid $1 \mathrm{~mol} / \mathrm{L}(50 \mu \mathrm{g} / \mathrm{mL}$ before degradation, B2); and hydrocortisone sample degraded with hydrogen peroxide $3 \%\left(50 \mu \mathrm{g} / \mathrm{mL}\right.$ before degradation, B3). C: Nifedipine preparation in petrolatum initially (C 1) and after heating at $80^{\circ} \mathrm{C}$ for 3 days (C2). D: Nitroglycerine preparation in petrolatum initially (D1) and after heating at $80^{\circ} \mathrm{C}$ for 3 days (D2).

nitroglycerine stored in plastic containers. ${ }^{15}$ However, in the current study, the use of glass containers was not critical to the stability of the nitroglycerine preparation. Most likely, the petrolatum itself acts as an excellent chemical and physical stabilizer for nitroglycerine, as nonrelevant quantities were adsorbed or absorbed by the plastic container.

As expected, the presence of water in the cream base was detrimental to the stability of hydrocortisone. Use of petrolatum will increase the stability of this drug from 2 months to more than 12 months.

Use of hydrocortisone, nitroglycerine, and calcium-channel blockers, including nifedipine and diltiazem, has been reported in the treatment of anal fissures. Pain can be reduced by using steroidal anti-inflammatory agents, such as hydrocortisone. Furthermore, nitroglycerine and nifedipine are potent vasodilatory agents. These 2 drugs can increase local blood flow and stimulate fissure healing. ${ }^{5-11}$ The data presented in the current study confirm the stability of these 3 active ingredients when compounded in petrolatum. From a quality perspective, these results can be used to establish a BUD when dispensing these compounded products to patients.

\section{CONCLUSIONS}

Preparations of hydrocortisone $2.5 \%$, nifedipine $0.5 \%$, and nitroglycerine $0.2 \%$ in petrolatum remained stable for at least 12 months when packaged in white opaque polypropylene containers. This study provides data to support BUDs for these preparations and will allow compounding pharmacists to provide their patients with quality formulations for the treatment of anal fissures. In contrast, hydrocortisone $2.5 \%$ in a cream base remained stable for only 2 months under similar conditions. Most likely, hydrocortisone is subject to hydrolysis when a cream base is used.

References

1. Lund JN, Scholefield JH. Aetiology and treatment of anal fissure. Br J Surg. 1996;83(10):1335-44.

2. Cross KL, Massey EJDA, Fowler AL, Monson JRT. The management of anal fissure: ACPGBI position statement. Colorectal Dis. 2008;10 Suppl 3:1-7. 
3. Orsay C, Rakinic J, Perry WB, Hyman N, Buie D, Cataldo P, et al.; Standards Practice Task Force; American Society of Colon and Rectal Surgeons. Practical parameters for the management of anal fissures (revised). Dis Colon Rectum. 2004;47(12):2003-7.

4. Hananel N, Gordon PH. Re-examination of clinical manifestations and response to therapy of fissure-in-ano. Dis Colon Rectum. 1997;40(2):229-33.

5. Antropoli C, Perrotti P, Rubino M, Martino A, De Stefano G, Migliore G, et al. Nifedipine for local use in conservative treatment of anal fissures: preliminary results of a multicenter study. Dis Colon Rectum. 1999; 42(8):1011-5.

6. Katsinelos P, Kountouras J, Paroutoglou G, Beltsis A, Chatzimavroudis G, Zavos C, et al. Aggressive treatment of acute anal fissure with $0.5 \%$ nifedipine ointment prevents its evolution to chronicity. World J Gastroenterol. 2006; 12(38):6203-6.

7. Carapeti EA, Kamm MA, Phillips RK. Topical diltiazem and bethanechol decrease anal sphincter pressure and heal anal fissures without side effects. Dis Colon Rectum. 2000;43(10):1359-62.

8. Loder PB, Kamm MA, Nicholls RJ, Phillips RK. 'Reversible chemical sphincterotomy' by local application of glyceryl trinitrate. BrJ Surg. 1994; 81(9):1386-9.

9. Watson SJ, Kamm MA, Nicholls RJ, Phillips RK. Topical glyceryl trinitrate in the treatment of chronic anal fissure. Br J Surg 1996;83(6):771-5.

10. Simpson J, Lund JN, Thompson RJ, Kapila L, Scholefield JH. The use of glyceryl trinitrate $(\mathrm{GTN})$ in the treatment of chronic anal fissure in children. Med Sci Monit. 2003;9(10):PI123-6.

11. Lund JN, Scholefield JH. A randomised, prospective, double-blind, placebocontrolled trial of glyceryl trinitrate ointment in treatment of anal fissure. Lancet. 1997;349(9044):11-4. Erratum in: Lancet 1997;349(9052):656.

12. General Chapter $<1191>$ Stability considerations in dispensing practice. In: United States pharmacopeia 39-national formulary 34. Rockville (MD): United States Pharmacopeial Convention; 2016. pp. 1557-61.

13. General Chapter <795> Pharmaceutical compounding-nonsterile preparations. In: United States pharmacopeia 39-national formulary 34. Rockville (MD): United States Pharmacopeial Convention; 2016. pp. 617-26.

14. Matsuda Y, Teraoka R, Sugimoto I. Comparative evaluation of photostability of solid-state nifedipine under ordinary and intensive light irradiation conditions. Int J Pharm. 1989;54:211-21.

15. Yuen PH, Denman SL, Sokoloski TD, Burkman AM. Loss of nitroglycerin from aqueous solution into plastic intravenous delivery systems. J Pharm Sci. 1979;68(9):1163-6.

Mihaela Friciu, MSC

Research Associate

Amandine Chefson, MSC

Research Associate

Grégoire Leclair, BPharm, PhD

Associate Professor

Faculty of Pharmacy

Université de Montréal

Montréal, Quebec

Competing interests: None declared.

Funding: This study was funded by an unrestricted grant from Dr Stephen Morgan, colorectal surgeon, Hôpital Saint-Luc, Montréal, Quebec.

Acknowledgements: The authors are grateful to Dr Stephen Morgan (colorectal surgeon) for useful comments about the causes and treatment of anal fissures, and to Philip Morgan (pharmacist) for useful comments about current preparations used to treat this condition. 